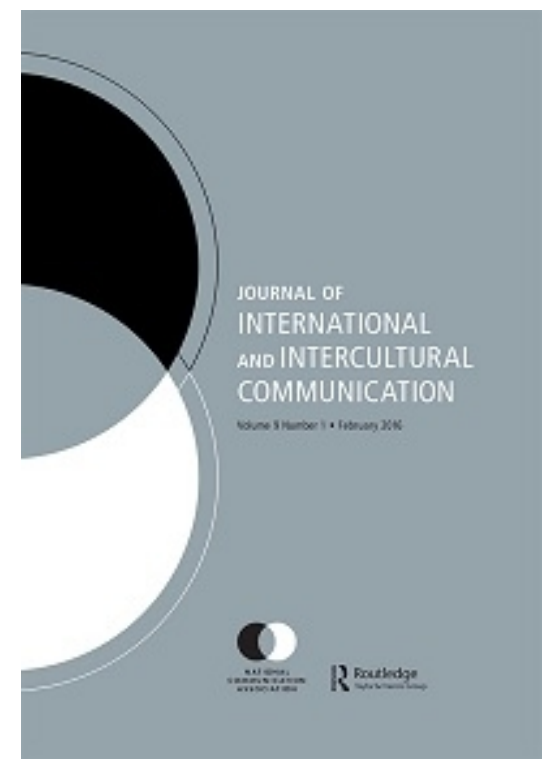

\title{
Communicating Citizenship in China's Digital Society
}

\begin{tabular}{|r|l|}
\hline Journal: & Journal of International \& Intercultural Communication \\
\hline Manuscript ID & RJII-18-Mar-0011.R2 \\
\hline Manuscript Type: & Special Issue Paper \\
\hline Keyword: & Citizenship, Speech codes, Online discourse, Chinese internet \\
\hline \multicolumn{2}{|l}{} \\
\end{tabular}

\section{SCHOLARONE} Manuscripts 


\section{Communicating Citizenship in China's Digital Society}




\begin{abstract}
This research explores the (inter-) cultural dimension of communicating citizenship in China's new media environment. It adopts speech codes theory (Philipsen et al., 2005) as a theoretical and methodological framework to examine the historically situated and socially constructed meanings of Chinese citizenship and the normative communicative conduct for practicing "good citizenship" in China. Through a systematic analysis of online blog posts and comments surrounding two social events, this study captures one speech code pertaining to communicating citizenship in China that is premised on a paradox - citizenship is interpreted by the Chinese as a legal entitlement that they deserve, but at the same time it is also treated as an aspirational and unattainable ideal. Moreover, speaking sensibly and morally with a public and communal orientation is heavily emphasized in this speech code as it is considered a valuable communicative conduct for practicing "good citizenship" in China. Additionally, participating in online collective actions such as "topping posts" is rendered an acceptable and effective way to communicate and enact citizen rights.
\end{abstract}

Keywords: Citizenship, Speech codes, Online discourse, New media 


\title{
Communicating Citizenship in China's Digital Society
}

\author{
Citizenship, a "momentum concept" (Hoffman, 2014, p. 12) of our time, has been \\ intensively investigated by scholars from various disciplinary backgrounds. Over the past two \\ decades, communication scholars have made significant contributions to this field of research by \\ theorizing and analyzing citizenship (both as a concept and a practice) from a communicative \\ perspective. This perspective in general views citizenship as a communicative construct that is \\ interactionally accomplished and constantly reconfigured through discourse (Cheng, 2018; \\ Ivanyi, et al.2006; Livio, 2017; Sbisà, 2006). From this perspective, scholars have explored the \\ rhetorical and cultural dimensions of crafting and enacting citizenship in a given socio-political \\ environment, focusing on the discursive maneuvering of "citizenship-making" in its local context
} (Asen, 2004; Cheng, 2018; Kock \& Villadsen, 2012, 2017; Livio, 2017). Instead of treating citizenship as a relatively stable legal status or political membership granted to selected members in the (nation-) state; a communication approach seeks to capture ongoing interactive processes through which members claim their citizen identity and rights while negotiating with established structures - be they legal, political, or moral. This approach focuses on exploring questions that are central to understanding how people in a polity articulate themselves into citizens (Asen, 2004; Isin, 2008; Milani, 2015), how they construct their citizen identity through "othering" other groups in society (Kock \& Villadesn, 2017; Shafir \& Peled, 2002), and how they negotiate their political and social self-understanding through locally-situated and globally-disseminated linguistic and cultural practices (Cheng, 2018, 2018; Livio, 2017; Milani, 2015; Stroud, 2009). Viewing citizenship communicatively entails two different but complementary interpretations. The first interpretation, manifested in some of the scholarly work mentioned above, is oriented toward "a constitutive cornerstone of citizenship in the sense that meaningful 
communication is inextricably associated with perceptions of what it means to be a citizen and what rights this entails" (Livio, 2017, p. 2617). The communicative nature of citizenship can be witnessed, not simply at times of voting in general elections, but more often in series of daily communicative events (such as a public hearing or a family dinner) through which participants construct and negotiate different cultural meanings of citizenship. Secondly, citizenship is communicative in that an individual's right to communicate (i.e., to speak and to be heard meaningfully in public) constitutes a supreme component of citizenship (Livio, 2017, p. 2606). The linkage between individual citizens and their right to communicate has been well noted in previous studies, especially in those examining cultural ways of speaking in American public settings (Carbaugh, 2005; Edgerly, 2011; Leighter, 2007; Philipsen, 1992). Carbaugh (2005), for instance, observed a cultural premise concerning the action of speaking as an essential part of being a citizen in American public discourses, stating that "citizens are not only entitled to speak in public freely as codified in the First Amendment, but are also expected to do so" (p. 90).

Notably, a citizen's right to communicate is inherently tied to their civil, political, and social rights as stated in Marshall's (1950) seminal work. Viewing citizenship communicatively does not dismiss other renderings of citizenship and citizen rights, such as Rosaldo's (1997) influential work on cultural citizenship; nevertheless, this communicative conceptualization captures a distinct and important aspect of how people in a polity construct citizenship as a meaningful term for them to identify with in their day-to-day life and how they do this communicatively.

The question of how citizenship is constructed and interpreted in a particular context is further complicated by the changing forms and patterns of citizen participation in a digital environment. Communication scholars have noted that new forms of citizen participation in 
peer-defined social networks (e.g., the creating and spreading of user-generated content, forming networks, and organizing online petitions) have contributed to changes in the nature of citizenship itself in terms of civic norms and practices, and what constitutes "good citizenship" (Bennett, et al., 2011; Kligler-Vilenchik, 2016, 2017). Although the role of new media in changing conceptions and practices of citizenship still remains hotly debated, most scholars tend to agree that these changes are amplified and enhanced in the digital environment. For example, Kligler-Vilenchik (2017) reviewed different citizenship models developed in Western democracies over the last two decades and synthesized a broader inter-disciplinary paradigm of “alternative citizenship models," based on, for example, Zuckerman's (2014) model of participatory civics and Cohen and Kahne's (2012) model of participatory politics. These alternative models, as the author contends, not only describe new forms of citizenship (which value self-expression, creativity, direct individual and collective action) in a changing media landscape, but also illuminate the role of new media in reshaping citizenship.

The present study explores the idea of citizenship as a communicative construct in China's digital environment, with a particular focus on the cultural dimension of communicating what it means to be a citizen and what rights it entails for people in China participating in online commentary surrounding two social controversies ${ }^{1}$. Given the extensive research on citizenship in democratic societies from the Western sphere (Cheng, 2018; Nuyen, 2002), it is of great value to investigate how citizenship is communicated and interpreted in an ever-changing society like China - ruled by a single-party state and deeply influenced by Asian cultural traditions such as Confucianism and Buddhism (Chen \& Starosta, 2003). The current study adopts Philipsen's speech codes theory (Philipsen, et al., 2005) to examine the historically situated and socially constructed cultural meanings and premises pertaining to communicating citizenship in Chinese 
online public discourses. It seeks to discern discursive moves and culturally situated speech codes invoked by online participants to interpret and communicate their citizenry identity and rights in China's digital society, through an analysis of online talk and interactions related to the Chinese concept of citizen, namely, 公民/gongmin ${ }^{2}$. The analysis demonstrates one speech code concerning citizenship in China's digital environment that is premised on a somewhat paradoxical interpretation of citizenship both as a legal entitlement which the Chinese deserve and at the same time, as an aspirational and unattainable ideal. Speaking sensibly and morally with a public and communal orientation is highly valued as the normative conduct for the Chinese to practice "good citizenship." With the affordances of technologies such as the Internet and smartphones, “topping posts 3 " ( 顶帖/dingtie) has been associated with practicing citizenship in China and it is considered an acceptable and effective way to enact citizen rights by some participants.

The remainder of this manuscript is structured as follows. First, I will historicize the study of citizenship in China by focusing on the trajectory of the term gongmin and showing how it was interpreted and used by Chinese intellectuals and political leaders across different historical periods. This description of the trajectory is further extended to an overview of recent scholarly work on Chinese people's civic participation on the Internet. Next, I will explain the rationale behind the data collection, and the theoretical and analytical framework used in this research. In the analysis section, I will highlight the cultural premises and rules related to the communicative construction and enactment of Chinese citizenship in the data. Finally, this manuscript concludes with a discussion of the implications of studying citizenship communicatively in China's digital society and beyond. 


\section{Citizenship in China}

The concept of citizenship in modern China emerged in the late nineteenth century under Western influence, at a time when Chinese intellectuals were eagerly searching for ways to rebuild the collapsing Qing Empire as a strong nation-state in the face of Western imperialism and internal pressures (Zarrow, 1997). Liang Qichao (1873-1929), one of the most influential intellectuals and reformists of that time, proposed (see quotes below) that in order to transform the late Qing empire into a modern nation-state, it was necessary to change Chinese people to be self-disciplined and morally autonomous "citizens" instead of ignorant and passive "subjects" under imperial rule. Liang's proposal, in tandem with the thinking of other prominent Chinese intellectuals (e.g., Kang Youwei and Sun Yat-sen), considered the renewal of Chinese people through citizen education and civic training as the only solution to China's various problems. As historian Joan Judge (1997, p. 165) argued, the greatest challenge Chinese reformists such as Liang faced in the early twentieth century was "not Western gunboats or foreign technology, nor institutional restructuring or constitutional law," it was 'the people' - "the anonymous, unknowable, and often dreaded $\min$, excluded from participation and power."

"All countries have the same sun and moon, all have mountains and rivers, and all consist of people with feet and skull; but some countries rise while others fall, and some become strong while others are weak. Why? ... I know the reason. A state is formed by the assembling of people. ... If we wish the nation to be secure, rich, and honored, we must discuss the way for 'renewing the people.'”' Liang Qichao, 1902, (de Bary \& Lufrano, 2000, p. 289)

The notion of citizenship (and citizen) entered the Chinese context in the late nineteenth century under Western influence. Since then, not only was this term often talked about as an essentially Western idea, the actual meaning of citizenship also changed over Chinese history 
under the rule of different political authorities (Goldman \& Perry, 2002; Zarrow, 1997).

Throughout the $20^{\text {th }}$ century, different conceptions of citizenship were imposed by Chinese political authorities (such as the Nationalists and the Communists) on the populations living under their control. This variation has resulted in bewildering fluctuations in defining citizenship boundaries (i.e. who are included and excluded) and meanings (i.e. who citizens are and what they do) in contemporary Chinese public discourses.

\section{The Chinese term 公民/gongmin}

Perhaps because of its strong connotation with the "public spirit" ${ }^{4}$, the Chinese term 公 民/ gongmin (literally meaning "public people") became one of the Chinese expressions of “citizen,” along with several other distinctive terms such as 人民/renmin (the people), 国民 /guomin (nation-state people), and 市民/shimin (city people) (Goldman \& Perry, 2002; Harris, 2002). Although for late imperial and republican-era intellectuals, these terms were used interchangeably to link the Chinese populace with a modern nation-state (Chen, 2004). Each of these terms designates membership in rather different communities, highlights distinct aspects of the Chinese state-society relations, and more importantly, provides a pivot point of reference for intellectuals and politicians to imagine a modern nation-state, a citizenry, and civil society in the Chinese context. The term 国民/guomin (nation-state people), for example, was adopted by late imperial reformist Liang Qichao to push his nationalistic political agenda of involving the populace in making China into a modern nation-state, rather than developing autonomous individuals within the state (Goldman \& Perry, 2002; Guo, 2015, Harris, 2002). For Liang and late Qing intellectuals alike, 国民/guomin was clearly a preferred term to designate the populace as "citizens" of China in that the "nation" (国/guo) was literally positioned before the "people" 
(民/min). The "nation" weighed more than "the people" in Chinese intellectuals' blueprint of rebuilding China, and the strong sentiment of “nationalism” in late Qing and Republican-era elites' discourse around guomin was very evident (Guo, 2014). In fact, during the period 1903-1915, this term surpassed gongmin and shimin in the press ${ }^{5}$ and became the most popular rendering of “citizen" (Guo, 2014). However, over the course of the twentieth century, gongmin has largely replaced guomin and became the widely accepted category (in both official and public discourses) to refer to persons who are legally recognized as members of a state (Goldman \& Perry, 2002).

When Kang Youwei (1858-1927), a prominent political thinker and reformer of the late Qing dynasty, advocated the implementation of "local self-government" (difang zizhi) with an involved citizenry in 1902, he defined 公民/gongmin as, "Whoever has lived in a locality for a number of years, 20 years old or over, has a clean (qingbai) family background, never committed any crime, can afford to give alms to the poor, can pay ten dollars worth of tax, may qualify as citizens" (Lee, 1998, p. 41). According to Kang's definition, the concept of gongmin is not only associated with a location (or a living place) and age, but also a person's economic standing and moral qualifications. By these criteria, only a small group of Chinese elites enjoyed the privileges of being a citizen. This restrictive categorization of citizenship did not seem to be problematic for Kang in that he actually "insisted on a sharp distinction in privileges between those who are citizens and those who are not" (Lee, 1998, p. 41). There was almost a consensus among late Qing intellectuals that the majority of Chinese populace was deemed not yet ready to participate in the political transformation of a two-thousand-year-old feudal China to a modern nation-state. Nevertheless, late imperial intellectuals held a strong belief in each Chinese person's capacity to become a better person. Kang Youwei was one of them. He maintained that 
by not granting citizenship automatically to everyone, the disqualified majority would be inspired to improve themselves to be a full-fledged citizen so that they can elect local officials and assemblies, as well as stand for election. These political rights were regarded as privileges enjoyed only by qualified Chinese elites who earned their title of gongmin through their financial achievements, social backgrounds, and moral qualifications.

Moral qualifications, as shown in Kang's definition of gongmin, were considered the most important aspect of an involved citizenry who could look beyond themselves and share the responsibility and the burden of nation-building through their political participation and self-rule at the local level. The imagination of a highly motivated and morally disciplined group of gongmin was essentially a result of the interaction between the Chinese neo-Confucianism and Western constitutionalism (Lee, 1998). Despite Kang's restrictive proposal of membership in this category, the Chinese expression of gongmin (as a rendering of the English word "citizen") became the vehicle through which the populace came to learn and practice political citizenship from their western counterparts in terms of the duties, obligations, and rights of members of society in late Qing and Republican-era China. The translation of "citizen" (either as gongmin or guomin), as Guo (2015, p. 17-18) argued, helps to develop new kinds of political discourse and foster the imagination of a new polity with a different relationship between state and society in modern China.

This new discourse of "citizenship," however, had to give way to the rhetoric of "class" emphasizing collectivism, class status, and the party line during the Mao era (1949-1976). As historians have noted, the opportunity to become a citizen with substantial political rights as well as responsibilities may have seemed possible during the first half of the twentieth century, but the aspiration to be a “comrade” (同志/tongzhi) under the influences of Marxism and Mao’s political 
thoughts surpassed Chinese people's political passion of becoming a citizen (Goldman \& Perry, 2002; Guo, 2015). In fact, during this time, the term 公民/gongmin (as citizen) hardly appeared in Chinese public discourse except in formal, legal, and propaganda documents (Keane, 2001; Li \& Wu, 1999). It was not until 1953 that 公民/gongmin was articulated in the Law of Election of the People's Republic of China (PRC) and then in the first constitution of the PRC enacted in the following year. This constitution spelled out Chinese citizens' (中国公民/zhongguo gongmin) basic legal, political and civil rights, but did not define the membership boundary of this category, that is, who can be a Chinese citizen? This question was not answered until 1982 when the revision of the constitution clearly indicated that whoever holds the nationality of the PRC is a citizen of PRC. It is interesting to note that unlike "the people" (人民/renmin) that is written into the Chinese constitution as "the master of the state", gongmin largely remains a legal concept based on its constitutional definition. Moving into the post-Mao era and with Deng Xiaoping's Reform and Opening Up policy, the concepts of "citizen" and "citizenship" reentered the Chinese context and it was at this time that the Chinese intellectuals unanimously translated “citizen” as 公民/gongmin. Unlike the discussion of citizens in the early decades (with a heavy focus on state-building), the meaning of gongmin since the mid-1980s has taken people's political, legal, and civil rights as its bases. In particular, this political "right consciousness" associated with gongmin spread from the educated elites to the general population of workers, peasants, the growing middle class, and religious groups (Goldman, 2005). Chinese expressions such as gongmin yishi (citizen consciousness), gongmin quan (civil rights) and gongmin shenfen (citizenship) became part of the common vocabulary for the educated elites and ordinary common people alike. More importantly, these terms became the crucial political leverage for 
individuals to struggle for and protect their rights, especially for those marginalized individuals in society.

With the technological affordance of ICTs in the twenty-first century, Chinese people's struggle for citizen status and political rights surged unprecedentedly, not only on the internet, but also in China's urban streets, public parks and remote villages (Cai, 2010). Much of the work on citizenship in China supports the argument that gongmin's "right consciousness" expanded dramatically in Chinese society since the late 1990s and naturally extended into China's cyberspace despite the government's repression and online censorship (Goldman, 2005). However, as Keane (2001) observed, the concept of gongmin itself remains ambiguous and even problematic when the Chinese leaders and political elites tried to incorporate a moral component, or gongde (civic virtue), into the notion and practice of citizenship in the context of China's market economy. Moreover, the denial of citizen-related civil rights and freedoms in China's official discourse made many people feel disillusioned about their self-identification as "citizens of China".

\section{Citizen Participation in China's Digital Society}

Recent Chinese Internet studies show that the use of the Internet in China has not only facilitated a new discourse space for self-expression, civic engagement, and political participation (Lagerkvist, 2010; Yang, 2009), but also generated new buzzwords and expressions for the Chinese to make sense of their citizen identity (Link \& Xiao, 2013a, 2013b; Szablewicz, 2014; Yang, et al., 2015) and their relationship with the ruling state (Hartford, 2005; Herold, 2011a). Within this new discourse space, Chinese citizens can voice their concerns and opinions, form alliances, fashion a new identity and new forms of civic engagement and political participation. For instance, since 2010, Chinese Internet users have started to use the term 屁民 
Ipimin (shitizen) to communicate their interpretation of what it means to be a citizen in China. Calling themselves "shitizens" instead of "citizens," these users express their shared sense of powerlessness and disenfranchisement as members of the Chinese state (Yang, et al., 2015). Pimin (literally meaning "fart people"), as a somewhat playful expression of citizenship in contemporary China, is clearly laden with political meaning in that "fart people" itself communicates a power imbalance (and an antagonistic relationship) between ordinary Chinese citizens and the ruling state/officials, that is, "ordinary people are like farts to officials."

Chinese people's interaction with the Internet also demonstrated novel communicative practices through which political participation and civic engagement are accomplished. Herold (2011b) pointed out that Chinese netizens had initiated a number of "human flesh searches" 6 against corrupt and criminal officials; and as a result, most of these officials either lost their position or had been arrested. Some of these most well-known cases, such as the Lin Jiaxiang event $^{7}$ and the Deng Yujiao event ${ }^{8}$, were often cited in academic and public discourses as evidence of a changing China where netizens' spontaneous and collective actions succeed in punishing (local) government officials' misconduct (Herold \& Marolt, 2011; Li, 2016; Link \& Xiao, 2013a). Although it is still debatable whether these collective efforts will eventually be translated into long-term social-political change in China, there is a consensus among scholars about the potential of this kind of political human flesh search (or "human hunting") for targeting official misconduct at the local government level. In addition, “online surrounding gaze” (网络 围观/wangluo weiguan) is another newly emerged common practice among Chinese Internet users. As Teng (2012) observed, online surrounding gaze in China today has been transformed into a synonym for active political participation, in sharp contrast to what this expression of "surrounding gaze" implicates in "old China" - indifference and bleakness as depicted in the 
famous Chinese literary critic Lu Xun's writings. For many people in China, joining online crowds for a "surrounding gaze" is what they call 'micro revolution' (Tong \& Lei, 2013). It is the main venue for them to protest in China. In some sense, doing "nothing" is everything. "Surrounding", "gazing", and "witnessing" are all forms of actions that the Chinese Internet users are capable of to practice civic engagement and political participation.

The above discussions about the history of citizenship and citizen (公民/gongmin) in modern China and newly emerged identifications and practices for citizen identity and participation in China's new media environment, prompt the question of how citizenship is communicated in China's digital society. How do people in China make sense of their citizen identities in and through their communicative conduct within a new discourse space facilitated by the Internet? To shed light on this question, this study collected a data sample of Chinese public discourse pertaining to online discussions of citizenship and adopted speech codes theory as a theoretical and methodological framework to analyze the data.

\section{Data Collection}

The data sample for this study was selected from a large corpus of online posts (including blog posts and comments) concerning two social events on Chinese social media sites. The first controversy relates to the notorious "Zhou Jiugeng Event" in 2008. Zhou was a municipal government official (i.e. Director of the Housing Department) in Nanjing, the second largest city in the East China region. He was suspected of being corrupt after Chinese Internet users posting pictures of him wearing different luxury watches at several occasions. A collective "human flesh search" was soon initiated on the Internet by Chinese netizens to find out "the truth" behind his overtly luxurious lifestyle. As more evidence was unveiled online, the public started to press the local government to take actions. After an eight-month investigation, the Nanjing government's 
intermediate court charged Zhou's with corruption in August 2009 and subsequently sentenced him to 11 years in jail. The second event in 2013 featured a Chinese woman fiercely arguing with approximately twenty law enforcement officers in front of her house about whether she had the right to put her flower-stand on a pedestrian street. This interaction was witnessed by a big crowd of Chinese tourists since this woman's house resides in a very touristy area in Xiamen, a scenic coastal city in China's southeast. Many witnesses recorded this interaction and posted it on Youku, one of the most popular online video-sharing websites in China. Unlike other "shortlived" online events, these two events attracted wide public attention and generated heated discussions over a time span of two years on Chinese social media.

I used the commercial web scraper WebHarvy (https://www.webharvy.com/) to automatically extract online posts and comments on the two events mentioned above. Roughly 80,000 posts were collected and all of them are in Mandarin Chinese. Given the interest of this research in discerning speech codes associated with the Chinese cultural ways of speaking as citizens, a more specific data sample is compiled based on three keyword searches, respectively, citizen, 公民, and gongmin) in the large corpus. As a result, 676 posts were retrieved after omitting duplications. These posts were then scrutinized, coded, and classified into two broader categories pertaining to 1) constructed meanings of the Chinese citizen identity and 2) the practice of "good" citizenship. In light of the insights from Philipsen (1997) and Carbaugh (2005) about indigenous symbols and expressions as meta-communicative (i.e. indexing cultural ways of being, relating and so on), I focused my analysis on online commentators' use of the Chinese terms of citizenship (particularly 公民/gongmin) following the two coding categories mentioned above. Based on this analysis, I identified the constituent elements of a speech code related to communicating citizenship in China's digital society. 


\section{Theoretical Framework}

Speech Codes Theory was developed by communication scholar Gerry Philipsen and his associates to explore human communicative conduct from a cultural perspective (Philipsen, 1992; Philipsen et al., 2005). Speech codes are defined as "a system of socially-constructed symbols and meanings, premises, and rules, pertaining to communicative conduct" (Philipsen, et al., 2005, p. 57). From this point of view, human communicative conduct is deeply cultural, and culture can be invoked and experienced as speech codes in ordinary day-to-day communication. Every culture (or speech community) has its own distinctive speech codes which are shared among members of the community. These codes not only allow members to assign particular meanings to communicative conduct, but can also index meta-communicative messages about human nature, personhood, social relations, and the rhetorical nature of human communication. In addition to interpreting the meaningfulness of communicative conduct through speech codes, members may also be able to invoke a specific code to predict, evaluate, and even control the communicative conduct of others who subscribe to the same speech code.

Speech codes are formulated based on researchers' observation and analysis of human communicative conduct in a particular time and place. According to Philipsen et al. (2005, p.62), "the key to noticing and describing speech codes is to watch communicative conduct and listen to it." Since speech codes are inextricably woven into the act of speaking, naturally occurring speech from participants provides a rich source for the study of these codes (Kotani, 2016). As such, the current study renders online talk and interactions (in the form of blog posts and comments) as another important mode of communication that is deeply intertwined with culturally salient premises and rules that participants on the Chinese Internet invoke to construct their sense of citizenship. 


\section{Citizenship as an Aspirational Identity and an Unattainable Ideal}

Chinese online commentators treat the notion of citizenship as essentially something "foreign" to identify with, and they problematize the use of this identity expression in the current political environment. As shown in the data examples below, commentators asserted that citizens do not exist in China. This assertion may sound very presumptuous, but it indicates the commentators' sheer dejection and ruthless mocking of the lack of both citizen rights (公民权利 /gongmin quanli) and civic awareness (公民意识/gongmin yishi).

Data Examples $1.0^{9}$

C1 我们的祖先都当过这个国家的公民？？？

All our ancestors had been citizens of this country???

C2 张总我们中国有公民吗? 身份证个个都是写着居民吧！

Boss Zhang do we have citizens in China? Isn't it on everyone's national ID card where it says resident!

\section{C3 我们的身份证上写的是居民，我们没有公民的权利啊}

On our national ID card it says resident, we don't enjoy the rights of a citizen

\section{C4 你住这就是租的。果然我们并不是公民，我们只是中国租民}

(The house) you're living in is rented to you. As expected we are not citizens, we are just China's tenants.

Commentators in $\mathrm{C} 1$ and $\mathrm{C} 2$ raised the question of whether there had ever been "citizens in China". Their question was apparently rhetorical as they implicitly projected a negative answer in their comments. The implication is not only that people in contemporary China cannot be seen as "citizens" but also that citizenship (along with associated political, legal, and civil rights as embedded in Western societies) is some kind of ideal form of being that had never been attained, neither in the past, nor in the present. Similarly, commentators in C3 and C4 disapproved of labeling themselves as Chinese "citizen" but instead used the categories of 
"residents" (in C2 and C3) and "tenants" (in C4) to identify themselves. Their selection of categories other than "citizen/gongmin" seems to highlight their political status as someone merely residing in China without enjoying the rights of being citizens of China. In C3, the commentator confirmed this interpretation by attributing their "resident" identity to the lack of citizen rights.

This selection of "residents" (and "tenants") over "citizens" with a sarcastic tone, becomes particularly revealing when we take into consideration the original dispute in the second social event to which they were responding. The dispute between the Chinese woman and law enforcement officers was not just about putting a flower stand outside on a public street, but also about the ownership of houses and land more generally in China. As such, the commentators' emphasis on referencing themselves as "residents" can be seen as a strategic discursive move to echo the lack of what the Chinese woman was arguing for, that is, the protection of citizens' human rights and their private property rights. By labeling themselves as merely "resident" and "tenant" of China, these commentators lamented the deprivation of their citizen rights by the Chinese state. This assessment of their own situation contrasts markedly with their idealized view of citizenship which has been deeply influenced by Western liberalism. As these commentators suggested, this idealized notion of citizenship was unattainable for the Chinese, not because the lack of a proper term for describing them as citizens but rather the unfortunate reality of not being treated as citizens entitled with rights. Although this sentiment was widely shared by other online commentators, it does not rule out the possibility that other commentators expressed aspirations for performing citizen identity and enacting citizen rights in China, especially when it comes to the practice of "good citizenship." The analysis in the following section will shed light on this observation. 


\section{Practicing Good Citizenship: Speaking Sensibly with Moral Virtues}

Despite this disparaging view of "citizen in China" (as shown in Data Examples 1.0), many online commentators categorize the Chinese woman in the second social event as a citizen (公民/gongmin) (See Data Examples 1.1 below). Her doughty and aggressive style, as well as her seemingly sensible way of speaking in front of law enforcement officers, won her millions of supporters on the Internet, along with the identity of being "a good citizen" (in C6). Interestingly, during her whole interaction with law enforcement officers, this woman never referred to herself as a citizen. Nevertheless, as shown in the Data Examples 1.1, all the commentators claimed (implicitly and explicitly) that this Xiamen woman was not just a “citizen" but more importantly a "good and highly qualified citizen". The commentator in C5, for example, marked this woman as "a legendary instantiation of a citizen." This discursive marking echoes the claims made by commentators in $\mathrm{C} 2-\mathrm{C} 4$ about the non-existence or the rarity of citizens in China, and moreover treats this woman's communicative conduct as a citizen something spectacular and extraordinary. Commentators in $\mathrm{C} 6, \mathrm{C} 7$, and $\mathrm{C} 8$ all highlighted the woman's ability to reason, to speak truthfully and sensibly, to abide by the law, and to make her appeal through legal and non-violent means. Among these descriptors of "good citizens", “speaking sensibly” (讲道理/jiang daoli) in C6 and C8 stands out as the most salient. The Chinese expression 讲道理 (speaking sensibly) can take on different meanings from one situation to the next. It can be interpreted as a principle of respecting the truth and reasons in interaction, or as a particular way of speaking with sense and reasonableness. In the current context, this woman's ability to reason, to speak truthfully, nonviolently, and forcefully in front of law enforcement officers was applauded by online commentators as the defining feature of good citizens. 
Data Examples 1.1

C5 那什么，我先回味一下。这个大姐......是不是......就是.......传说中的公民 啊 ? ?

Well, let me ponder it for a while. This big sister...isn't she...exactly...the legendary citizen??

\section{C6 鼓浪屿的大姐讲道理摆事实.......是良好守法公民 !}

This big sister on Gulangyu island presented the facts and talked reasonably...(she) is a good citizen abiding by the law!

\section{C7 真心为这位公民鼓掌也为城管和公安最后的撤离鼓掌在中国，合理表达真实诉 求的权利以及对这一权利的尊重都太难得}

I sincerely applauded this citizen, as well as for the city inspectors and policemen in China who eventually retreated; nowadays, it is just so hard to see (people in China) exercising the right of reasonably making an appeal as well as (government officials') respect of this right.

C8 一位普通的妇女的公民权益，真正的中国公民一个，中国需要这样不暴力但能 讲理的公民，我为这位中国公民叫好

An ordinary woman's citizen rights, (she is) a true Chinese citizen, China needs such kinds of citizens who are nonviolent and can speak sensibly, I applaud this citizen of China.

\section{C9 我想说中国各地要是都多有几个这么“虎悍”公民 中国就是需要这样有公民意识 的人}

I want to say if only every place in China had a few "doughty" citizens (like her), China just needs this kind of person who has civic awareness.

\section{$\rightarrow \mathrm{C} 10$ 这个垃圾国度有几个这样合格的人类公民 ? 中国只要有百分之一的人民 具备这种公民素质}

In this trashed nation how many qualified citizens of this kind do we have? If only one percent of the people in China had this kind of citizen qualifications.

$\rightarrow \mathrm{C} 11$ 这才是公民意识，赞！讲道理，讲法治，讲人权。

Only can this be called civic awareness, awesome! Speaking sensibly, speaking the rule of law and human rights.

In addition, "civic awareness" (mentioned in C9, C10 and C11) emerged as another critical characteristic of highly qualified citizens in China. The commentator in $\mathrm{C} 9$, for example, 
claimed that the woman (who was described as "doughty" in the original online video of her interaction with those officers) was not just a "doughty citizen" but more importantly a citizen with civic awareness. Following up, commentators in C10 and C11 regarded "civic awareness" as an essential and ideal qualification for Chinese citizenship but they went on to state that only a small number of people can attain this quality.

While many online commentators lauded this woman as a role model for practicing "good citizenship", others questioned her communicative conduct in this dispute from a moral and legal perspective. Like the commentators in Data Examples 1.1, commentators below also regarded this woman as a "citizen", but they challenged her communicative conduct of a "good citizen" by highlighting her "moral defect" (see C12), her "unlawful acts" (see C13), and her "bias" against law enforcement officers (see C14). These commentators argued that being able to "speak sensibly" does not necessarily contribute to "good citizenship" and that the woman was not actually practicing "speaking sensibly." In Data Examples 1.2, the commentator in C12 contended that this woman lacked "civic virtues" even though she was capable of using human rights to reason with the law enforcement officers. Similarly, the commentator in C13 raised questions about this woman's invoking of "human rights" in her interaction with city inspectors. Both commentators in $\mathrm{C} 12$ and $\mathrm{C} 13$ seemed to suggest that speaking of "human rights" in this context was inappropriate and illegitimate in that this woman was mainly using this as a defense to serve her personal interests at the expense of the communal/public interests. The "civic virtues" in $\mathrm{C} 12$, as well as the interests of her neighbors (as citizens) in C13, were brought up as a leverage to raise questions about the moral "goodness" and reasonableness of this woman's communicative conduct as a citizen. They argued that prioritizing a citizen's personal interest over the "public" or "communal interest" is not an acceptable way of enacting citizen rights. This 
argument was further expanded in C14 when the commentator openly expressed a concern about the communal and the societal impact of this woman's defiance of the law because of her personal bias against these officers. This commentator activated a larger frame within which the communal and societal implications of this woman's communicative conduct was highlighted and questioned. In this sense, this woman's active engagement with law enforcement officers by speaking eloquently was not considered by these online commentators as a culturally legitimate way of practicing citizenship, let alone "good citizenship."

Data Examples 1.2

\section{C12 可惜她只知道拿人权社会来称道却忽视公民道德的基本内涵}

It's too bad that she only knew how to reason by referring to human rights but dismissed the basic connotations of civic virtues.

\section{C13 南方一贯拉偏架 那举报叫城管来的邻居们就不是公民了？ 就没人权了？}

In the south, it's typical to mediate between two quarrelling parties with bias. So those neighbors who reported (unlawful acts) and called city inspectors to the site are not citizens? They don't have human rights?

\section{C14 这样是不对的，如果公民因为对城管有意见就不守法，那么社会会怎样？}

This is not right, if citizens defy the law because they bear a grudge against city inspectors, then what would (our) society be like?

These commentators' moral critique of this woman's communicative conduct as a “citizen” implicates a defining feature of citizenship embedded in China's traditional political culture, that is, the intrinsic orientation to the "public" and "communal" (公/gong) in the practice of citizenship. This orientation may not be only particular in the Chinese context (and to some extent it may share cultural interpretations of citizenship within the Western discourse), but it does reveal a communal and relational aspect of being in the public realm which has been heavily emphasized in the writings of Chinese political philosophers and thinkers, such as the Confucian celebration of "public service" (Goldman \& Perry, 2002) and Han Feizi's promotion 
of the "public people" over "private protégés" in feudal China (Chen, 2004). Cheng's (2018) recent work on understanding citizenship through terms of relationships (e.g., mothers and sisters) in modern Taiwanese discourse also points to the communal and relational dimension of citizenship in Chinese societies. This contingency illustrates an important historical conjuncture in understanding ordinary people's interpretation and practice of citizenship in contemporary China, especially regarding the moral dimension of communicating citizenship. Traditional values such as “acting for the public or communal interests" (为公/wei gong) and "civic virtues" (公民道德/gongmin daode) remain crucial elements in the Chinese speech code about citizenship in public discourse.

\section{Communicating Citizen Rights: Topping Posts Online}

Online commentators also expressed their concerns about Chinese citizens exercising their rights, especially regarding their political right of supervising and monitoring the government within the current political system. On the one hand, they agonized over the dismal political environment in China and its restrictions on citizens' political actions; while, on the other hand, they applauded the Internet as a powerful platform for them to exercise their rights in spite of limitations. Online posts on the first social event demonstrates this political dimension of communicating citizenship in China’s digital society. In Data Examples 1.3, commentators in $\mathrm{C} 15, \mathrm{C} 16$, and $\mathrm{C} 17$ all implied that it is normative for Chinese citizens to supervise and monitor their government. This act of supervising (监督/jiandu) -regarded as an “obligation” and a "principle" of being an ordinary citizen (in C16 and C17)-is premised on the affordances of the Internet in Chinese society. The exposure of the corrupt official Zhou Jiugeng provided a classic example of Chinese citizens exercising their right of supervising those in power (Herold, 2011b). 
Similarly, commentators in $\mathrm{C} 16$ and $\mathrm{C} 17$ referred to their participation in online discussion as the only means by which they can exercise their rights and fulfill their obligations as citizens.

Data Examples 1.3

C15 本案是不是应该作为公民监督 ZF 的一个经典案例呢?

Shouldn't we consider this case (Zhou's case) a classic example of citizens supervising the government?

\section{C16 第一次行使了一个普通公民的举报义务....}

For the very first time I, as an ordinary citizen, fulfilled my obligation of reporting on a corrupt official.

\section{C17 面对这个社会，我也只有在天涯，才能找到作为一个公民的准则}

In this society, only in Tianya (a BBS forum) can I find the principle of being a citizen.

Unlike the positive tone indicated in the Data Example 1.3, some commentators expressed their deep concern and frustration about citizens' political rights in Chinese society. In C18, the commentator indicated his/her frustration through being “speechless” (无语/wuyu) about being a Chinese citizen who can do nothing but topping posts online. This comment implies that citizens are entitled to political rights and therefore they should be provided with adequate means to participate in politics and supervise the government; but in reality; what they could do was "only topping posts online" (in C18). This deep sorrow is communicated through the commentator's "speechless" response to Chinese government's corruption. Commentator in C19 also describes Chinese citizens as "having no power, no money, no status," as such, the only alternative for them to act against corruption is to rely on their collective action online. In this sense, "topping posts online" becomes a "reasonable communicative conduct" (as indicated in C20) for online commentators to perform their citizen identity, and more importantly to enact their right to communicate (i.e. to speak and to be heard meaningfully) in China's political environment. 


\section{Data Examples 1.4}

\section{C18 无语中......作为一个公民我能为国家做的也许只能是顶帖了。}

Being speechless...... as a citizen perhaps what I can do for this country is only to top others' posts (online).

\section{C19 当权力监督的滞后与无力当腐败的横行与露骨拿什么捍卫正义啊有良知的公民 们我们没有权力没有金钱没有地位唯有用一道道微弱的呐喊汇集成呛人的洪流涤荡 社会的文明}

When the oversight on power became lagging and impotent and when corruption became undisguised and prevailing, by what means can we defend justice? Conscientious citizens, we have no power, no money, nor status, thus the only way we have is to collect many a feeble scream into a raging torrent to clean the society.

\section{C20 兄弟们 我们都是小老百姓，甚至连公民都算不上号召下，我们没有太多能做 的让我们天天来顶这样的帖子，让大家都看看什么是公仆}

Brothers, we are all petty common folks, cannot even be called citizens. In response to this call (for anti-corruption), there's not much we can do. Let's come (online) and top posts like this one every day and let everyone see what public servants are like.

The commentator in C20 claimed that people like him (i.e., the "brothers") can only be considered as "petty common folks," "not citizens" because "there is not much" they can do. The implied assumption is that "citizens" enjoy rights and thus they are able to enact their rights in their everyday life, particularly concerning citizens' political rights in this case. Because of this restricted access to participating in political decision-making, this commentator announced (seemingly to an imagined collective audience) that "topping posts" is the right alternative for the Chinese to enact their political rights such as monitoring and reporting on officials in power. All the commentators in this data example alluded to this undesirable reality where citizens' political, legal, civil, and economic rights are denied or restrained; nevertheless, they embraced this alternative way of communicating their diminished citizen rights by collectively participating in online posting and hoping that leads to a change in politics. 


\section{Discussion}

Citizenship (and citizen rights) as practiced in Western democracies remains an unattainable social and political aspiration for the Chinese. Online commentators either referred to themselves as "citizens of China" while simultaneously disclaiming their citizenship identity; or they talked themselves as "residents in China" while longing for political, legal, and civil rights associated with citizens. What this indicates is a deeply felt communicative dilemma for the Chinese pertaining to how they conceive and communicate their citizen identity, to claim their citizen rights, and to directly participate in political life. Many online commentators are not comfortable talking about themselves as "citizens" because they do not think they are exerting their entitled rights and freedoms as citizens in Western democracies would normally do. Many of them attempt to find a balance between this entitlement and the unattainable ideal of citizenship in their comments. For some commentators, labelling themselves as "Chinese citizens" is a strategic discursive move to aspire and embrace an ideal form of citizenship rooted in Western democracy and, at the same time, to ridicule their lack of rights in China's political environment. Moreover, these commentators' identification with being merely "residents" (or “tenants"), similar to Chinese Internet users' self-categorization as “shitizen/fart people” (Link \& Xiao, 2013a) and "diaosi/loser" (Szablewicz, 2014; Yang, et al., 2015), reveals how they interpret what it means to be and how it feels like a citizen in China.

Because of their disillusions with the government and the deprivation of their citizen rights, online commentators resort to the Internet as the only available platform for them to participate in deliberating and administrating state affairs. This gap between the imagined "ideal citizenship" and Chinese citizens' actual restrained enactment of rights through their communication creates perplexing and occasionally contradictory discourses about the cultural 
meanings of citizenship. These contradictions and contestation on Chinese citizenship constitute essentially what citizenship means for the Chinese. Based on this analysis, I propose the following speech code pertaining to communicating citizenship in China's new media environment. This speech code is premised on this paradoxical interpretation of citizenship as a legal entitlement that the Chinese deserve but at the same time it remains aspirational and unattainable. Speaking sensibly and morally with a public/communal orientation is considered the defining feature of communicating and practicing "good citizenship" in China. Participants" active contestation of meanings often demonstrates the dynamic and constructive nature of speech codes (Edgerly, 2011). In this case, online commentators' contestation of "good citizenship" captures this ongoing interactive process through which members of one more multiple online speech communities construct and negotiate the constituents of speech codes about communicating and interpreting citizenship in contemporary China.

Although there are divergent views on whether an individual can be considered as a good/qualified citizen, the emphasis on serving the public or communal interest and moral virtues underpins a culturally distinctive way of communicating and interpreting citizenship. Similar to Cheng's (2018) discussion of "relational citizenship" in the cultural framing of citizenship in Taiwan with regard to foreign spouses, this public-orientation and moral virtues are deemed highly crucial for, not only communicating citizenship, but also evaluating the appropriateness of this communication. Moreover, in China's digital society, the communicative practice of "topping posts online" has been linked with the exertion of citizen rights for the Chinese. It is through participating in this collective form of topping online that many people in China come to see themselves as citizens enacting their right to supervise on the government and participate in political affairs. 
The paradox about Chinese citizenship lends support to Michael Keane's (2011) claim that the notion of citizenship remains problematic in contemporary China. This problem is perhaps most significantly manifested in online commentators' ultimate claim about China having no "citizens," but only "residents" and "tenants." For these commentators, the term citizen (公民/gongmin) is still too alien a category for them to identify with (even after two hundreds years). This is not just because citizen was originally a foreign concept, but more importantly because of the lack of an enabling political system and environment in China to prevent the state infringing upon people's rights to act as citizens.

Citizenship is regarded as an unattainable social and political dream due to the jeopardization of citizen rights in China. Online commentators seem to be very aware of this mismatch between how citizens are talked about in China's official discourse (i.e. being endowed with political, civil, and economic rights) and how citizens are treated in reality (i.e., being deprived of citizen rights). Nevertheless, some commentators are still willing to entertain the possibility of exerting their rights as citizens in response to the two online events, but from different perspectives. In the Zhou Jiugeng case, commentators emphasized the facilitating role of the Internet in helping them foster a sense of citizenship through their online actions such as topping posts. They recognized the limitations of these seemingly unimportant online actions, but they seem to believe in the collective power of these online activities to make a difference. In other words, participating in these online activities such as "witnessing" and "topping posts" constitutes and enacts their citizenship. In the Chinese woman's case, it is her "qualities" (e.g., speaking sensibly) that elevates her as a model citizen above other ordinary citizens or "petty common folks". In this sense, the citizen membership is confined to "qualified individuals" who are able to "earn" their citizen rights under the current political climate through their 
performance of these qualities such as speaking sensibly and morally. In both cases, the practice of citizenship and the exertion of citizen rights are recognized by online commentators as very limited or even not existent in China, but the majority of them engage in constructing an ideal form of citizenship that is influenced by both Western democracies and China's traditional political culture. For instance, a public and moral orientation (为公/weigong), stands out as a culturally distinctive way of defining and communicating citizenship and citizen rights in contemporary China.

A communication-oriented view offers significant insights into the communicative practices of citizenship-making in China's digital society. As Livio (2017, p. 2616) demonstrated in his analysis of Israeli public discourse, citizenship is a multilayered, complex, and often contradictory concept, and "acquires its cultural meanings from the everyday discourse engaged in by citizens...”. The current study lends its support to this observation by illustrating the contestation of good citizenship and the communicative dilemma about claiming citizen identity and rights. China's new media environment seems to have provided an alternative venue for disillusioned Chinese to negotiate new meanings of citizenship and foster novel practices for exerting citizen rights through their interaction with the Internet. 


\section{References}

Asen, R. (2004). A discourse theory of citizenship. Quarterly Journal of Speech, 90(2), 189-211.

Bennett, W. L., Wells, C., \& Freelon, D. (2011). Communicating civic engagement: Contrasting models of citizenship in the youth web sphere. Journal of Communication, 61(5), 835856.

Cai, Y. (2010). Collective resistance in China: Why popular protests succeed or fail. Stanford, CA: Stanford University Press.

Carbaugh, D. (2005). Cultures in conversation. Routledge. Mawah, NJ, and London: Lawrence Erlbaum Associates, Inc.

Chen, Y. (2004). 辛亥革命时期公民权利思想的启蒙 [The awakening of civil rights during the revolution of 1911], 福建师范大学学报(哲学社会科学版) [Fujian Normal University Journal/ Philosophy \& Social Sciences], 5, 86-93.

Cheng, H. (2018). Relational citizenship: Examining Taiwanese membership development through immigrant framing in public discourses. Journal of International and Intercultural Communication, 11(2), 154-172.

Cohen, C. J. \& Kahen, J. (2012). Participatory Politics: New Media and Youth Political Action. Chicago, IL: MacArthur Foundation.

de Bary, W. T. \& Lufrano, R. (2000). Sources of Chinese Tradition: From 1600 Through the Twentieth Century (2 ${ }^{\text {nd }}$ edition, vol. 2). New York: Columbia University Press.

Edgerly, L. (2011). Difference and political legitimacy: Speakers' construction of "citizen" and "refugee" personae in talk about Hurricane Katrina. Western Journal of Communication, 75(3), 304-322. 
Goldman, M. (2005). From Comrade to Citizen: The Struggle for Political Rights in China. Cambridge, MA: Harvard University Press.

Goldman, M. \& Perry, E. (2002). Changing Meanings of Citizenship in Modern China. Cambridge, MA: Harvard University Press.

Guo, Z. (2014). 立民与立国: 中国现代国家构建中的话语选择 [From citizen-building to statebuilding: How intellectuals imaged the political discourse in modern China?] 武汉大学 学报/哲学社会科学 [Wanhan University Journal/ Philosophy \& Social Sciences], 67 (3), 56-62.

Guo, Z. (2015). The emergence of the citizen concept in modern China: 1899-1919. In Z. Guo \& S. Guo (eds.) Theorizing Chinese Citizenship (pp. 3-22). Lanham: Maryland, Lexington Books.

Harris, P. (2002). The origins of modern citizenship in China. Asia Pacific Viewpoint, 43 (2), 181-203.

Hartford, K. (2005). Dear Mayor: Online communications with local governments in Hangzhou and Nanjing, China Information, XIX (2), 217-260. doi: 10.1177/0920203X05054682

Herold, D. K. (2011a). Supervision for the middleman? Active Citizenship as basis for good governance in the P. R. China in International Conference on "Governance and Citizenship in Asia: Paradigms and Practices", 18-19 March, 2011, Hong Kong

Herold, D. K. (2011b). Human flesh search engines: Carnivalesque riots as components of a “Chinese democracy.” In D. K. Herold \& P. Marolt (Eds.), Online Society in China: Creating, celebrating, and instrumentalising the online carnival (pp. 127-145). New York, NY: Routledge. 
Herold, D. K. \& Marolt, P. (2011). Online Society in China: Creating, celebrating, and instrumentalising the online carnival. New York, NY: Routledge.

Hoffman, J. (2004). Citizenship beyond the state. Sage.

Isin, E. F. (2008). Theorizing acts of citizenship. In: Isin, Engin F. and Nielsen, Greg M. eds. Acts of Citizenship. London, UK: Palgrave Macmillan, pp. 15-43.

Ivanyi, Z., Kertesz, A., Marinecz, K., \& Mate, N. (2006). Personal reference, social categorization and the communicative achievement of citizenship: Comments on a local public meeting on GMO field trials. In H. Hausendorf \& A. Bora (eds.), Analyzing Citizenship Talk: Social Positioning in Political and Legal Decision-making Processes (pp. 223-250). Amsterdam: John Benjamins Publishing Company.

Judge, J. (1997). Publicists and populists: Including the common people in the late Qing new citizen ideal. Imagining the People: Chinese Intellectuals and the Concept of Citizenship, 1890-1920, 142-165.

Keane, M. (2001). Redefining Chinese citizenship. Economy and Society, 30 (1), 1-17.

Kligler-Vilenchik, N. (2016). Good citizenship as a frame contest: Kony 2012, memes, and critiques of the networked citizen. New Media \& Society, 18 (9), 1993-2011.

Kligler-Vilenchik, N. (2017). Alternative citizenship models: Contextualizing new media and the new “good citizen.” New Media \& Society, 19 (11), 1887-1903.

Kotani, M. (2016). Two codes for remedying problematic situations: Japanese and English speakers' views of explanations and apologies in the United States. Journal of Intercultural Communication Research, 45 (2), 126-144.

Kock, C., \& Villadsen, L. S. (Eds.). (2012). Rhetorical citizenship and public deliberation. University Park, PA: Pennsylvania State University Press. 
Kock, C., \& Villadsen, L. S. (2017). Rhetorical citizenship: studying the discursive crafting and enactment of citizenship. Citizenship Studies, 21(5), 570-586.

Lagerkvist, J. (2010). After the internet, before democracy: Competing norms in Chinese media and society. Bern: Peter Lang.

Lee, L.M.T. (1998). Local self-government in late Qing: Political discourse and moral reform. The Review of Politics, 60 (1), 31-53.

Leighter, J. L. (2007). Codes of commonality and cooperation: Notions of citizen personae and citizen speech codes in American public meetings (Doctoral dissertation, University of Washington).

Li, B. \& Wu, Y. (1999). The concept of citizenship in the People's Republic of China. In A. Davidson \& K. Weekley (eds.), Globalization and Citizenship in the Asia-Pacific (pp. 157-168). London, UK: Macmillan Press.

Li, G. (2016). The emergence of the Human Flesh Search Engine and political protest in China: Exploring the Internet and online collective action. Media, Culture \& Society, 38 (3), 349-364. DOI: $10.1177 / 0163443715610493$

Link, P. \& Xiao, Q. (2013a). China at the tipping point? From "fart people" to citizens. Journal of Democracy, 24 (1), 79-85.

Link, P. \& Xiao, Q. (2013b). From grass-mud equestrians to rights-conscious citizens. In P. Link, R. P. Madsen, \& P. G. Pickowicz (eds.) Restless China (pp. 83-106). Lanham, Maryland: Rowman \& Littlefield Publishers, Inc.

Livio, O. (2017). Citizenship as a communicative construct. International Journal of Communication, 11, 2605-2623.

Marshall, T. H. (1950). Citizenship and social class (Vol. 11, pp. 28-29). Cambridge. 
Milani, T. M. (2015). Language and citizenship: Broadening the agenda. Journal of Language and Politics, 14(3), 319-334.

Nuyen, A. T. (2002). Confucianism and the idea of citizenship. Asian Philosophy, 12 (2), $127-$ 139.

Philipsen, G. (1992). Speaking culturally: Explorations in social communication. Albany: State University of New York Press.

Philipsen, G. (1997). A theory of speech codes. In G. Philipsen \& T. Albrecht (Eds.), Developing Communication Theories (pp. 119-156). Albany, NY: State University of New York Press.

Philipsen, G., Coutu, L. M., \& Covarrubias, P. (2005). Speech codes theory: Restatement, revisions, and response to criticisms. Theorizing about intercultural communication, 5568.

Rosaldo, R. (1997). Cultural citizenship, inequality, and multiculturalism. Latino cultural citizenship: Claiming identity, space, and rights, 2738.

Sbisà, M. (2006). Communicating citizenship in verbal interaction. In H. Hausendorf \& A. Bora (Eds.) Analysing Citizenship Talk: Social positioning in political and legal decisionmaking processes (Vol. 19). Amsterdam: John Benjamins Publishing. (pp. 151-180).

Shafir, G., \& Peled, Y. (2002). Being Israeli: The dynamics of multiple citizenship (Vol. 16). Cambridge University Press.

Stroud, C. (2009). Towards a Postliberal Theory of Citizenship. In International Perspectives on Bilingual Education: Policy, Practice and Controversy John E. Petrovic (ed.) pp. 191218. New York: Information Age Publishing. 
Szablewicz, M. (2014). The ‘losers' of China's Internet: Memes as 'structures of feeling' for disillusioned young netizens, China Information, 28(2), 259-275.

Teng, B. (2012). Rights defense (weiquan), microblogs (weibo), and the surrounding gaze (weiguan): The rights defense movement online and offline. China Perspectives, 3, 2941.

Tong, Y. \& Lei, S. (2013). War of position and microblogging in China. Journal of Contemporary China, 22 (8), 292-311.

Yang, G. (2009). The Power of the Internet in China: Citizen Activism Online. New York: Columbia University Press.

Yang, P., Tang, L., \& Wang, X. (2015). Diaosi as infrapolitics: scatological tropes, identitymaking and cultural intimacy on China's Internet. Media, Culture \& Society, 37 (2), 197 214.

Zarrow, P. G. (1997). Citizenship in China and the West. In J. A. Fogel \& P. G. Zarrow (Eds.) Imagining the People: Chinese Intellectuals and the Concept of Citizenship, 1890-1920. (pp. 3-38). Armonk, New York: M. E. Sharpe, Inc.

Zuckerman, E. (2014). New media, new civics? Policy and Internet, 6 (2): 151-168. 
Footnotes

${ }^{1}$ For a detailed account of these two events, please refer to the section on Data Collection.

${ }^{2}$ The English term citizen (-ship) has multiple Chinese translations throughout the 20th century. It is not until 1954 when the First Constitution of the People's Republic of China (PRC) was passed that the Chinese term 公 民 (gongmin) was used as an official translation of citizen (-ship) in English.

${ }^{3}$ Topping posts (顶帖/dingtie in Chinese) is a jargon term used by commentators on the Chinese Internet. It refers to the communicative act of propping up a post in a discussion forum in order to make it appear and stay on the front page of the forum for better visibility. This is a very common and popular practice that many online commentators participate in, usually through a short reply to the original post with one or two words or simply a reply with no words posts.

${ }^{4}$ According to Goldman and Perry (2002), Mary Rankin and William Rowe argued that the Chinese concept 公/gong (public) in late imperial China bears resemblance to the Habermasian "public sphere" in that under the name of gong Chinese elites actively participated in political discussion, public deliberation and local activism.

${ }^{5}$ According to Guo (2014), the term 国民/guomin appeared in Chinese public discourse (e.g., newspapers, journals articles, public speeches, etc.) much more frequently than 人民 (renmin) and 公民 (gongmin) during 19031915, especially in 1903.

6 “Human flesh search" (人肉搜索/renrou sousuo), the Chinese expression for searching and digging out personal information in the Internet (such as Google), is a collective means of information sharing for the purpose of tracking down individuals (typically the ones who are exposed online as breaking norms or moral values upheld by majority members of Chinese society) from the virtual world to "offline China." It relies on collective efforts from Chinese netizens to share and contribute information about the target person. According to Herold (2011b), RRSS is a normative online practice for the Chinese to pursue their personal interest (e.g., finding out a run-away wife), to express their mob anger over widespread stories from individuals (e.g., a foreign English teacher's blogs disclosing his sexual conquests of Chinese girls in Shanghai) and to protest against government officials (e.g., the Zhou Jiugeng case in this study and the Lin Jiaxiang incident in 2008).

${ }^{7}$ Lin Jiaxiang, the Party secretary of the Shenzhen marine affairs office, was accused of attempting to molest an 11-year old girl in a restaurant while Lin was drunk. When confronted by the little girl's parents, Lin shouted at the parents, "you people are like a fart, my rank is the same as your Mayor's." Accidentally, this interaction was caught on the restaurant's surveillance camera and was later posted on the Internet. Angered by Lin's remark, netizens started a human flesh search on him and eventually found out who he was. The central government took the incident very seriously and Lin was immediately sacked after this, although he was cleared of all criminal charges due to a lack of conclusive evidence.

${ }^{8}$ Deng Yujiao was a young worker at a foot massage center in a hotel in Hubei province. In 2009, when a group of officials were attempting to sexually assault her, she defended herself with a knife and accidently killed one of the officials. Later she was charged with homicide after she called the police and gave herself up. After Deng's case was covered in national media, many netizens suspected that Deng was found guilty because the deceased official was a high rank official in the local government. So they took actions online. They started a RRSS to identify all the people involved in the assault and forced the police to start a proper investigation into Deng's case. In the end, Deng was released and the involved officials were punished (Herold, 2011b)

${ }^{9}$ All translations of the data examples are provided by the author. These translations are meant to be literal translations partly because of the concern with keeping an authentic feel of the original data and partly because of the author's interest in online commentators' use of meta-communicative vocabularies in their comments. 